DOI: 10.17707/AgricultForest.64.3.01

\author{
Božidarka MARKOVIĆ, Milan MARKOVIĆ, \\ Snežana TRIVUNOVIĆ, Slavko MIRECKI, \\ Zvonko ANTUNOVIĆ, MiljanVELJIĆ ${ }^{1}$
}

\title{
EFFECTS OF THE ALPHA S1-CASEIN GENOTYPE ON MILK YIELD AND MILK COMPOSITION OF BALKAN GOAT IN MONTENEGRO
}

\section{SUMMARY}

The objective of this study was to investigate genetic polymorphism of the alpha S1 casein gene and its association with milk production parameters (milk yield and milk composition) of indigenous Balkan goat breed reared in Montenegro. Two genetic variants (A and F) and three genotypes AA, AF and FF of alpha S1-casein have been identified. The analysis showed a prevalence of strong A allele (0.626) compared to the weak $F$ allele (0.374), while the frequencies of genotypes were $0.398,0.456$ and 0.146 respectively. The effect of genotype of alpha S1 casein on the total milk yield, length of lactation and daily milk yield was not significant ( $>0.05$ ), while it is significantly influenced to the milk composition parameters. Goats with AA genotype of alpha S1 casein had significantly higher $(\mathrm{p}<0.001)$ average content of protein $(3.54 \%)$ than AF and FF genotype (3.40\% and 3.33\%). The same genotypes order were for fat content and solid non-fat content $(\mathrm{AA}>\mathrm{AF}>\mathrm{FF})$ with significant differences $(\mathrm{p}<0.05)$ of AA genotype in comparison to $\mathrm{AF}$ and $\mathrm{FF}$.

Genetic characterization of the alpha S1-casein gene contributes to the knowledge of the genetic structure of Balkan goat breed in Montenegro. These results could be important for establishing of the concept of conservation and sustainable use of this indigenous goat breed, as well as for selection scheme and breeding program.

Key words: goat, milk, alpha S1 casein, polymorphism

\section{INTRODUCTION}

One of the most valuable components in goat milk is protein. In goat milk, as in the other domesticated ruminants, total milk protein contains two main whey proteins ( $\alpha$-lacto albumin and $\beta$-lacto albumin) and four casein proteins $(\alpha \mathrm{S} 1$-casein, $\alpha \mathrm{S} 2$-casein, $\beta$-casein, $\kappa$-casein). These four caseins are expressed and encoded by CSN1S1, CSN2, CSN1S2 and CSN3 genes, respectively (Martin

\footnotetext{
${ }^{1}$ Božidarka Marković (corresponding author: bmarkovic@t-com.me), Milan Marković, Slavko Mirecki, Miljan Veljić, University of Montenegro, Biotechnical Faculty, Department of Livestock science.MihailaLalića 1, 81000 Podgorica, MONTENEGRO, Snežana Trivunović, University of Novi Sad, Faculty of Agricultural, Department of Animal Science. Dositeja Obradovića 8, 21000 Novi Sad, SERBIA, Zvonko Antunović, University of J.J. Strossmayer, Faculty of Agriculture, Department for Animal Husbandry, Vladimira Preloga 1, 31000 Osijek, CROATIA

Notes: The authors declare that they have no conflicts of interest. Authorship Form signed online.
} 
et al., 2002; Clark and Sherbron, 2000). The casein accounts approximately $80 \%$ of the total protein, while whey proteins stand for the remaining $20 \%$. Genetic polymorphisms of caseins are important and well known due to their effects on quantitative traits of milk and its technological properties. The casein at the locus alpha S1 is highly polymorphic and it is associated with the milk quality and composition, with some technological properties of the milk and also with the yield and quality of cheese (Martin et al., 2002; Roncada et al., 2002; Gómez et al., 2004;Feligini et al., 2005). Seven variants of as 1gene were identified initially (A, B, C, D, E, F and O), even more genetic variants and numerous possible allelic combinations (Grosclaude et al., 1987; Caravaca et al., 2011; Szatankoova et al., 2007).In the last decades several studies have reported that the remarkable genetic polymorphism at the as1-casein locus is greatly responsible for the individual variations observed in the casein content of the goat milk.

On the base more research the next expression levels are identified: strong alleles (A, B1, B2, B3, B4, C) associated with high content of as1-casein (3.5 $\mathrm{g} / \mathrm{l}$ ), intermediate alleles (E and I) associated with $1,1 \mathrm{~g} / \mathrm{l}$ of casein, weak alleles (D, F and G) synthesized at a low level (0.45 g/l) and null alleles (O1, O2, O3 and $\mathrm{N}$ ) characterized by absence of as1-casein in milk (Marletta et al., 2007; Torres-Vaskez et al., 2008,Feligini et al., 2005). Goat milks containing these "strong" variants ("strong" milks) are characterized by higher content of total protein, milk fat, calcium and more favorable cheese properties (coagulation properties, cheese yield and quality) than "intermediate", "weak" or "null" variants (Clark and Sherbon, 2000; Devold et al., 2011). Different protein content in goat milk affected by polymorphism of $\alpha$ s1-casein generates significant cheese yield differences (Moioli et al., 2007).

The effect of as1-casein polymorphism on goat milk quality was studied in different goat populations, but the most intensively in French breeds (Manfredi et al., 1995; Delacroix et al., 1996). These studies concluded that A allele has a significant positive effect on the whole milk protein, casein, fat contents and manufacturing properties (increasing cheese making efficiency up to 15\%), in comparison with $\mathrm{F}$ allele; $\mathrm{E}$ allele have an intermediary effect between the previous two. In dairy goat populations, it is often considered convenient to identify the alpha S1 genotypes of individual animals, with the idea of incorporating this information to the selection process for commercial breeds or to conservation program for autochthonous breeds (Moioli et al., 1998).

Goat production is one of the smallest livestock sectors in Montenegro (about 35,000 heads), but the sector with increasing trend in the last years. The main product of goat production is milk which is further processed into various types of cheese.

The objective of this study was to evaluate genetic polymorphism in the alpha S1 casein gene in Balkan goat breed from Montenegro by identifying genotypes and theirs association with milk production parameters (milk yield and milk composition). These information could be used in the program of conservation as well as for the selection and improvement of this breed. 


\section{MATERIAL AND METHODS}

The field study was carried out at two family farms of the Balkan goat breed, reared in south part of Montenegro characterized by Mediterranean climate. This is an autochthonous goat breed of the Balkan Peninsula and the most numerous breed in goat population of Montenegro. There are several varieties of Balkan goat breed regarding the color of hair, while red variety is the most typical in Montenegro. The system of rearing was semi extensive, based mostly on the grazing in hilly and rocky areas. Supplementing nutrition by concentrate feeds provided only during kidding time and in the beginning of the lactation and sometimes during summer season if vegetation is over dried and poor.

\section{Milk production traits}

Milk yield, recorded on the base of test day control, were carried out once a month during lactation period according to ICAR rules for AT control. Milk samples for the analysis of fat, protein and solid nonfat (SNF) content were collected for each test day(monthly) from all animals. The milk samples were analyzed in authorized laboratory by using infrared spectrophotometry on MilkoScan FT120.Milk recording and milk analysis are organized for bigger number of animals, but for this research used data and analysis performed on 103 animals which had both data - milk production parameters and genotype information.

\section{Genotyping of alpha S1 casein}

For DNA extraction, PCR amplification and sequencing blood samples (5 $\mathrm{ml}$ ) were taken from randomly chosen goats from above-mentioned two flocks. Samples were collected in EDTA tubes and stored at $+4^{\circ} \mathrm{C}$. A standard phenolchloroform protocol for DNA extraction from blood was used.

The sequence of 750 bp of $\alpha \mathrm{S} 1$-casein gene from exon 12 was amplified by PCR.

A typical 38cycles of PCR were carried out with the following PCR mixture: $10 \mu \mathrm{l}$ 10xPCR buffer (500 mMKCl, $200 \mathrm{mMTris}-\mathrm{HCl}, \mathrm{pH} 8.4) ; 8 \mu 1$ of $25 \mathrm{mM} \mathrm{MgCl} 2 ; 8 \mu 110 \mathrm{mM}$ of each dNTP, $0.5 \mu \mathrm{l}$ of $2.5 \mathrm{U}$ AmpliTaq DNA polymerase; $4 \mu \mathrm{l}$ of $10 \mathrm{pmol}$ of forward and reverse primers, $100 \mathrm{ng}$ goat genomic DNA and $\mathrm{ddH}_{2} \mathrm{O}$ up to $100 \mu$. The oligonucleotide sequences of the primers for amplification of sequence of the $\alpha \mathrm{S} 1$-casein gene were as follows:

Forward primer: 5' - CATTCTTTACTCCTGGGAAAG - 3';

Reverse primer: 5' - AGCACTTTTGGGAACAATTTC - 3'.

The following amplification conditions were used: denaturation; $1^{\prime}$ at $94^{\circ} \mathrm{C}$, annealing; $45^{\prime \prime}$ at $58^{\circ} \mathrm{C}$, extension; $1^{\prime}$ and $30^{\prime \prime}$ at $72^{\circ} \mathrm{C}$. The PCR productswere electrophoresed on $1.5 \%$ agarose.

Sequencing was carried out by ABI PRISM ${ }^{\circledR}$ BigDye ${ }^{\mathrm{TM}}$ Terminator Cycle Sequencing Ready Reaction Kit and the automatic DNA-sequencer Model 377 (PE Applied Biosystems, Wellesley, MA, USA). 


\section{Statistical analysis}

Statistical data processing for milking properties and alpha S1 casein genotypes was done using the general linear model (GLM) model in SPSS Statistics, version 20.

The GLM model used for calculation effect of genotype of alpha S1 casein and other factors to lactation length and total lactation milk yield had the following form:

$\mathrm{Y} i j k l=\mu^{+} \mathrm{F} i+\mathrm{Gj}+\mathrm{L} k+(\mathrm{FG}) i j+\mathrm{e} i j k l$,

While the model used for calculation effect of genotype alpha S1 casein and other factors to test day milk yield and milk composition had the following form

$Y i j k l=\mu+F i+G j+L k+C l+(F C) i l+e i j k l$

Yijkl - the phenotypic value of individual traits,

$\mu$ - general mean value,

F $i$ - fixed effect of the farms or flock, $(i=1,2)$,

$\mathrm{Gj}$ - fixed effect of the genotype of alpha $\mathrm{S} 1$ casein $(\mathrm{j}=1, \ldots 3)$

$\mathrm{L} k$ - fixed effect of number of lactation $(\mathrm{k}=1, \ldots 4)$,

$\mathrm{Cl}$ - fixed effect of the test days $(\mathrm{k}=1, \ldots 7)$,

(FG) $i j$ - interaction farm x genotype

(FC)il - interaction herd $\mathrm{x}$ test day,

eijkl -other undetermined effects (random error).

The frequency of alleles and genotypes and possible deviation from Hardy-Weinberg equilibrium were calculated by use Hardy-Weinberg equilibrium calculator (Rodrigueze et al., 2009).

\section{Genotypes of alpha $S 1$ casein}

The presence of two genetic variants of alpha S1-casein (A and F) determined by the sequencing of 750 base pairs long fragment of genomic DNA (between 3' end of intron 11 and 5' end of exon 13) which showed numerous single base substitutions, deletions and insertions. Allele A (A usually include A, $\mathrm{B}$ and $\mathrm{C}$ variants) dominated in the investigated population of Balkan goat breed in Montenegro with frequency 0.626, while the obtained frequency of weak allele $\mathrm{F}$ was 0.374 (Table 1). These two alleles (A and $\mathrm{F}$ ) appeared in three genetic forms, namely genotypes of alpha S1-casein (AA, AF and FF). The most common genotype was heterozygote AF (0.456), followed by the homozygote AA (0.398), while the FF genotype frequency was the smallest 0.146 .

According to the results of $\chi^{2}$ test, the investigated goat population was in Hardy-Weinberg equilibrium suggesting that the genotypes of alpha S1-casein was not influenced by selection.

Based on conducted results, the genetic structure of Balkan goat breeds corresponds to a high content of alpha S1 casein what is associated with domination of strong homozygote (AA) in comparison with weak heterozygote genotypes AF and FF. Polymorphisms at the locus of alpha S1-casein have been 
characterized in the most economically important goat breeds as well as in some local breeds from different countries (Kalamaki et al., 2014). Genotyping of as1casein and used as a selection criteria for dairy goat breeds (Alpina and Sannen) in some European countries has been carried out since the 1980s.

Table 1. Frequencies of genotypes and alleles and Hardy-Weinberg equilibrium test $\alpha \mathrm{S} 1$-casein gene of Balkan goat breed

\begin{tabular}{l|ccc|c|cc|c|c}
\hline \multicolumn{5}{c|}{ Genotypes of alpha S1-casein } & \multicolumn{2}{c|}{ Alleles } & \multirow{2}{*}{$\chi^{2}$} \\
\hline Parameter & AA & AF & FF & Total & A & F & $\chi^{2}=0.0657^{\text {ns }}$ \\
Ho & 41 & 47 & 15 & $\mathbf{1 0 3}$ & 129 & 77 & $\chi^{2}$ \\
He & 40.39 & 48.22 & 14.39 & & & & \\
Frequency & $\mathbf{0 . 3 9 8}$ & $\mathbf{0 . 4 5 6}$ & $\mathbf{0 . 1 4 6}$ & $\mathbf{1 . 0 0}$ & 0.626 & 0.374 & $\mathrm{P}=0.7975$ \\
\hline
\end{tabular}

Ho: observed heterozygotes, He: expected heterozygotes on the basis of HardyWeinberg, $\chi^{2}=$ chi-square value

The high prevalence of strong A allele (0.626) obtained in our analyses is similar to that found for many other unselected goats breeds such asSpanish Canaria breed, 0.60 (Jordana et al. 1996); Italian Gargancia breed, 0.61 (Martin, 1993), Balkan goat breed reared in Albania (0.47 - A and 0.46 B allele) and Damascus goat breed from Greece, 0.87(Grosclaude and Martin, 1997). High domination of strong alleles A and B obtained in seven African local goat breeds (Missohou et al., 2006) and in American dairy goats with African origin (La Mancha, Nubian and Nigerian dwarf) reported by Maga et al. (2009) .It is important to note that a frequency of weak $\mathrm{F}$ allele in the most of mentioned breeds was very low, even less than it is obtained for Montenegrin Balkan goat breed.

Since Montenegro is situated in South East Europe in Mediterranean area, the prevalence of strong A allele for Balkan goat breed is in accordance with several earlier studies which revealed that the genotypes with strong or medium alleles of the alpha S1-caseindominate among goat breeds from the Mediterranean region as Sarda, Maltese, Moroccan, Tunisian (Moioli et al., 2007), and within the Iberian Peninsula, in southern breeds as Murcianogranadina, Malageña or Payoya (Jordana et al., 1996; Caravaca et al., 2009). The prevalence of the A allele or of group of strong alleles (A, B and C) were also presented by Vlaic et al. (2010) for Carpatian goat breed, Caroliet al. (2007)for some African goats breeds and Kalamaki et al. (2014) for Greek-indigenous Skopelos goat.

Different from our results, on predominance of the intermediateexpressing(E) and weak-expressing (F) alleles, reported Maga et al. (2009) for America dairy goats (Alpine, Saanen, Togenburg, Oberhasli), and Soares et al. (2009) for Saanen and Alpina breeds reared in Brazil, as well as several earlier studies on dairy goat breeds in France and Italy (Grosclaude and Martin, 1997; Martin 1993). 


\section{Effect of alpha S1-casein genotype on the milk traits}

According to results presented in Table 2the autochthonous Balkan goat breed reared under extensive system in Montenegro is relatively low productive with average milk yield of $162.07 \mathrm{~kg}$, in lactation that lasted 215.9 days in average. In regarding of genotype of alpha S1 - casein the highest milk production (average daily milk yield and total lactation milk yield) obtained for heterozygote AF $(0.735 \mathrm{~kg} /$ day and $166.9 \mathrm{~kg})$, while the lowest milk yield obtained for goats with AA genotype of alpha S1 casein $(0.720 \mathrm{~kg} /$ day and 158.1 $\mathrm{kg}$ ), but differences among genotypes were not significant ( $\mathrm{p}>0.05)$.

Table 2. The means of alpha S1-casein genotypes for milk yield and milk composition traits in the studied goats

\begin{tabular}{|l|c|c|c|c|c|}
\hline & Genotype & N & Mean & S.E. & F -value \\
\hline \multirow{3}{*}{$\begin{array}{l}\text { Lactation duration, } \\
\text { days }\end{array}$} & AA & 41 & 211.2 & 3.83 & \\
\cline { 2 - 6 } & AF & 47 & 216.6 & 3.52 & \\
\cline { 2 - 6 } & FF & 15 & 220.4 & 5.29 & \\
\cline { 2 - 6 } & Total & 103 & 215.9 & 2.96 & $1.394^{\text {NS }}$ \\
\hline Lactation milk & AA & 41 & 158.1 & 6.34 & \\
\cline { 2 - 6 } & AF & 47 & 166.9 & 5.83 & \\
\cline { 2 - 6 } & FF & 15 & 161.1 & 8.76 & \\
\cline { 2 - 6 } & Total & 103 & 162.07 & 4.90 & $0.833^{\text {NS }}$ \\
\hline Daily milk yield, kg & AA & 243 & 0.720 & 0.017 & \\
\cline { 2 - 6 } & AF & 290 & 0.735 & 0.016 & \\
\cline { 2 - 6 } & FF & 92 & 0.717 & 0.024 & \\
\cline { 2 - 6 } & Total & 625 & 0.724 & 0.014 & $0.793^{\text {NS }}$ \\
\hline Fat, \% & AA & 243 & $3.491^{\mathrm{a}}$ & 0.042 & \\
\cline { 2 - 6 } & AF & 290 & $3.365^{\mathrm{b}}$ & 0.039 & \\
\cline { 2 - 6 } & FF & 92 & $3.295^{\mathrm{b}}$ & 0.059 & \\
\cline { 2 - 6 } & Total & 625 & 3.384 & 0.036 & $7.398^{* *}$ \\
\hline Protein, \% & AA & 243 & $3.537^{\mathrm{a}}$ & 0.0230 & \\
\cline { 2 - 6 } & AF & 290 & $3.404^{\mathrm{b}}$ & 0.027 & \\
\cline { 2 - 6 } & FF & 92 & $3.328^{\mathrm{b}}$ & 0.040 & \\
\cline { 2 - 6 } & Total & 625 & 3.423 & 0.023 & $18.646^{* * *}$ \\
\hline SNF, \% & AA & 243 & $8.532^{\mathrm{a}}$ & 0.0231 & \\
\cline { 2 - 6 } & AF & 290 & $8.442^{\mathrm{b}}$ & 0.029 & \\
\cline { 2 - 6 } & FF & 92 & $8.436^{\mathrm{b}}$ & 0.042 & \\
\cline { 2 - 6 } & Total & 625 & 8.467 & 0.025 & $5.282^{*}$ \\
\hline
\end{tabular}

SNF - solids non fat, Different letter in the superscript means statistical significant difference between means of genotypes $(p<0.05)$ which are in same column.

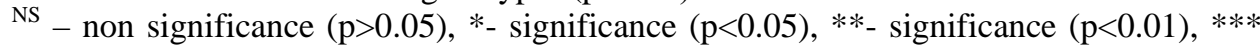
significance $(\mathrm{p}<0.001)$.

On the other side, milk composition parameters (content of protein, fat and SNF on the test day) have been significantly affected by genotype of alpha S1- 
casein $(\mathrm{p}<0.01)$. An average protein content for the whole investigated population was $3.42 \%$, while the goats with AA genotype of alpha S1 casein had higher content of protein than milk of AF and FF genotype by $0.13 \%$ and $0.21 \%$, respectively; those differences were significant $(\mathrm{p}<0.001)$.

The average fat content also was significantly higher in the goats milk with AA (3.491\%) than in goats with AF and FF genotype of alpha S1 casein (3.365 and $3.295 \%$, respectively). A similar effect of genotypes was also in the view of the content of SNF - the highest value for AA genotype was significantly different in comparison with the other two.

The autochthonous Balkan breed reared under extensive system of rearing in Montenegro is relatively low productive in regarding of total milk yield. The average milk yield of the studied population of Balkan goat breed reared under extensive condition in Montenegro was $162.07 \mathrm{~kg}$, in lactation that lasted 215.9 days in average is much lower than Bogdanović et al. (2010) referred for Balkan breed of goat reared under semi intensive condition in Serbia (378.4 kg in 256 days) and results of Kominakisa et al. (2000) for Greek Skopelos dairy goat (235 kg in lactation of 187 days). Our results are very similar to the results of milk production traits of Balkan breed on Kosovo and Albanian local breed (178 kg per lactation) displayed by Memisi et al. (2004) and Kume et al. (2012).In comparison with high productive dairy breeds, total milk yield and daily milk yield in Balkan goat are very inferior (Mioč et al., 2007; Klir et al., 2015, Slysius et al., 2017).These results, however, indicate that Balkan breed similarly as many autochthonous breeds, possesses a good biological variability, that could be easily used for increasing its production potential by improvement of nutrition, system of rearing and selection.

To meet the increasing interest for goat production and goats' dairy products, investigation of different milk parameters is very useful. The effect of polymorphism in the locus of alpha S1 casein on milk traits has been investigated in several countries for a long time, due to economic implications on goat milk processing into cheese.

Although a negligible negative effect of allele A and genotype AA of alpha S1 CN on milk yield was identified, in comparison to allele F, genotype of alphaS1 casein had no overall significant effect on total milk yield and daily milk yield. These results are in accordance with the results of Felícitas Vázquez et al.(2012).A slightly higher milk yield milkyield in AF and FF genotype than in AA genotype is in agreement with the results of Szatankoova et al. (2013) obtained for Check dairy goat.

A contrary to the previous finding, significant effect of the genotype of alpha S1 casein on milk composition is obtained. The close relationship of AA genotype with higher content of protein and fat is in agreement with many previous studies (Avondo et al., 2009, Szatankoova et al., 2007; Felícitas-Vaskez et al., 2012; Johansson et al., 2015). The higher protein content in goat milk which is influenced by polymorphism in alpha S1 casein gene resulting in higher cheese yield. (Feligini et al., 2005; Moioli et al.,2007; Maga et al.,2009). 
Though, the genotype of alpha S1 casein can be used as the selection criterion to improve these traits of goats.

As it claimed Boettcher et al. (2010) actions aimed to genotype for proved useful genes should be among the priorities for conservation of specific animal genetic resources, especially for breeds well adapted to difficult territories and rearing conditions as it Balkan goat breed. Generally, selection of animals for strong alpha S1-caseingenotype can lead to improvements in milk composition and quality, particularly in protein content and contribute to sustainable conservation of this breed.

\section{CONCLUSIONS}

This is the first study of genetic polymorphism of the alpha S1-casein gene of indigenous Balkan goat breed in Montenegro and their effect on milk production traits. The obtained results confirmed the existence of close association between the alpha S1-casein genotype and the parameters of milk quality in the investigated indigenous Balkan breed of goat. The proving of domination of "strong" allele A in the population of Balkan breed of goats and its associated with a higher content of protein in milk. Since A allele is desirable in regards of cheese production, it is very important because most of milk of this goat breed use for cheese production.

The next step in upgrading of these studies should be to investigate the effect of the alpha S1 casein polymorphisms on the technological characteristics of goat's milk. These results of the genetic diversity of Balkan goat breed reared under semi extensive conditions are the important argument for the conservation of its genetic diversity and consolidation because this breed very well adapted to local environment as well as for improvement of sustainable use of this indigenous goat population. Also, it would be possible to include the alpha S1 casein genotype in the selection scheme, as it is regular practice in developed countries.

\section{REFERENCES}

Avondo,M., Pagano, R.I., Guastella, A.M., Criscione, A., Di Gloria, M., Valenti, B., Lutri, L. and Pennisi, P. 2009. Effect of goat's alpha-s1 casein genotype on diet selection in a free choice feeding system. CIHEAM / FAO / NAGREF -Options Méditerranéennes :Série A. SéminairesMéditerranéens; n. 85, pg. 367 - 371.

Boettcher, P. J., Tixier-Boichard, M., Toro, M., Simianer, H., Eding, H., Gandini, G. and Consortium of Globaldiv 2010. Objectives, criteria and methods for using molecular genetic data in priority setting for conservation of animal genetic resources. Animal Genetics, 41(Suppl. 1), 1-14.

Bogdanović, V., Perišić, P., Đedović, R., Popović, Z., Mijić, P., Baban, M., Antunović, B. 2010. Characteristics of milk production traits of Balkan goats raised under "low-input” production systems. Mljekarstvo 60 (1), pg. 30-36.

Caroli, A., Chiatti, F., Chessa, S., Rignanese, D., Ibeagha-Awemu, E.M., and ErhardtG. 2007. Characterization of the casein gene complex in west african goats and description of a new as1-casein polymorphism. J. Dairy Sci. 90:2989-2996. 
Caravaca F., Ares J.L., Carrizosa J., Urrutia B., Baena F., Jordana J., Badaoui B., Sànchez A., Angiolillo A., Amills M., Serradilla J. M. 2011. Effects of $\alpha$ S1-casein (CSN1S1) and $\kappa$-casein (CSN3) genotypes on milk coagulation properties in Murciano-Granadina goats.Journal of Dairy Research78, pg 32-37.

Clark S., Sherbon J.W. 2000. AlphaS1-casein, milk composition and coagulation properties of goat milk. Small Ruminant Research 38, 123-134.

Delacroix-Buchet, A., C. Degas, G. Lamberet and I. Vassal 1996. Influence des variants $\mathrm{AA}$ et $\mathrm{FF}$ de la caséine $\alpha \mathrm{S} 1$ caprine sur le rendement fromager et les caractéristiques sensorielles des fromages. Lait, 76, 217-241.

Devold, T.G., Nordbø, R., Langsrud, T., Svenning, C., Jansen Brovold, M., Sørensen, E., Christensen, B., Ådnøy, T., Vegarud G. 2011. Extreme frequencies of the s1casein "null” variant in milk from Norwegian dairy goats- implications for milk composition, micellar size and renneting properties. Dairy Sci. \& Technol 91:3951.

Felícitas Vázquez, F., Montaldo, H.H., Torres -Vázquez, Alonso-Morales, R.O., Gayosso-Vázquez, A., Valencia-Posadas, M. and Castillo-Juárez, H. 2012. Additive and dominance effects of the as1-casein locus on milk yield and composition traits in dairy goats. Journal of Dairy Research (2012) 79 367-374.

Feligini, M., Frati, S., Cubrik Curik, V., Brambila A., Parma P., Curik I., Grepi G.F., and Enne G. 2005. Caprine alpha S1 - Casein Polimorphism: Characterisation of A, B, $\mathrm{E}$ and $\mathrm{F}$ Variants by Means of Various Biochemical and Molecular Technicues, Food Technology and Biotechnology, 43 (2) 123-132.

Gómez, J.Á.L; Miralles, B.; Agüera, P. and Amigo, L. 2004. Quantitative determination of as2- and as-1-casein in goat's milk with different genotypes by capillary electrophoresis. Journal of Chromatography A, vol. 1054, p. 279-284

Grosclaude, F., Mahe, M.F., Brignon, G., Di Stasio, L., Jeunet, R. 1987. A Mendelian polymorphism underlying quantitative variations of goat $\alpha \mathrm{S} 1$ - casein. Genetic, Selection and Evolution, 19, (399 - 412),

Grosclaude, F., Martin, P. 1997. Casein polymorphisms in the goat. Proceedings of the IDF Seminar held in North Palmerston, New Zealand.

Johansson, M., Högberg, M. and Andrén, A. 2015. Relation Between alph S1-Casein Content and Coagulation Properties of Milkfrom Swedish Dairy Goats. The Open Food Science Journal, 2015, 9, 1-4.

Jordana, J., Amills, M., Diaz, E., Angulo, C., Serradilla, M.J., Sanchez, A. 1996. Gen frequencies of caprine $\alpha \mathrm{S} 1$ - casein polymorphism in Spanish goat breeds. Small Ruminant Research, 20, 215 - 221.

Kalamaki, M.S., Gelasakis, SA.,Arsenos, G. 2014. Genetic polymorphism of the CSN1S1 gene in the Greek-indigenous Skopelos goat. Proceedings of the 4th ISOFAR Scientific Conference. 'Building Organic Bridges', at the Organic World Congress 2014, 13-15 Oct., Istanbul, Turkey (eprint ID 23947).

Klir, Ž.,Potočnik, K., Antunović, Z., Novoselec, J., Barać, Z., Mulc, D. And Kompan, D. 2015. Milk production traits from alpine breed of goats in Croatia and Slovenia. Bulgarian Journal of Agricultural Science, 21 (No 5), 1064-1068.

Kominakisa, A., Rogdakisa, E., Vasiloudisb, Ch., Liaskos, O. 2000. Genetic and environmental sources of variation of milk yield of Skopelos dairy goats. Small Ruminant Research 36, 1-5.

Kume, K., Papa, L. \&Hajno, L. 2012. Effects on milk production in F1 crossbred of Alpine goat breed $(\hat{)})$ and Albanian goat breed ( $(+)$.Italian Journal of Animal Science; volume 11:e47. Pg. 258-262.

Maga, E.A., Daftari, P.,Kültz, D.andPenedo, M.C.T. 2009. Prevalence of as1-casein genotypes in American dairy goat. J. Anim. Sci. 87:3464-3469. 
Manfredi, E., Ricordeau, G. Barbieri, M. E., Amigues, Y. and Bibé B. 1995. Génotype caséine $\alpha s 1$ et sélection des boucs sur descendance dans les races Alpine et Saanen. Genet. Sel. Evol. 27:451-458

Marletta, D., Criscione, A., Bordonaro, S., Guastella, A.M., D’Urso, G. 2007. Casein polymorphism in goat's milk.Lait 87:491-504.

Martin, P.; Szymanowska, M.; Zwierzchowski, L. And Leroux, C. 2002. The impact of genetic polymorphisms on the protein composition of ruminant milks. Reproduction Nutrition Development, vol. 42, no. 5, p. 433-459.

Memisi, N., Bauman, F., Stojanovic, S., Pavlov, B. and Jovanovic, S. 2004. Production characteristics of domestic Balkan goats. Animal genetic resources, Volume 35 April 2004 , pp. 87-94.

Mioč, B., Pavić, V., Barać, Z., Prpić, Z., Vnučec, I. 2007. Milk yield of some goat breeds in Croatia. Mljekarstvo 57 (1) 67-77.

Missohou, A., Talaki, E. and MamanLaminou, I. 2006. Diversity and Genetic Relationships among Seven West African Goat Breeds. Asian-Aust. J. Anim. Sci. 19(9):1245-1251.

Moioli, B., Pilla, F., Tripaldi, C. 1998. Detection of milk protein genetic polymorphism in order to improve dairy traits in sheep and goats: a review. Small Ruminants Research 27 (185 - 195).

Moioli, B., D’Andrea, M. and Pilla. F. 2007. Candidate genes affect-ing sheep and goat milk quality. Small Rumin.Res. 68:179-192.

Rodriguez S, Gaunt T.R. and Day I.N.M. 2009. Hardy-Weinberg Equilibrium Testing of Biological Ascertainment for Mendelian Randomization Studies. American Journal of Epidemiology Advance Access, DOI 10.1093/aje/kwn359.

Roncada, P.; Giviraghi, A.; Liberatori, S.; Canas, B. and Greppi, G.F. 2002. Identification of caseins in goat milk. Proteomics, June 2002, vol. 2, no. 6, p. 723-727.

Slyzius, E., Slyzienè, B., Lindziūtè, V. (2017): Factors affecting goat milk fat yield. Žemès Ükio Mokslai.Vol. 24.Nr. 3.Pg. 91-100.

Soares, M.A.M., Rodrigues, MT., Mogno, GP., Ribeiro, L.F.C., Silva, JL, Brancalhao, RMC. 2009. Polymorphism of alphas1-casein gene in a dairy goat herd in the southeastern region of Brazil. R. Bras. Zootec., v.38, n.6, p.1026-1032, 2009.

Szatankoova, Z.; Matlava, V. and Mala, G. 2007. Genetic polymorphism at the CSN1S1 gene in two Czech goat breeds. Czech Journal of Animal Science , vol. 52, no. 7, p. 199-202.

Sztankoova, Z., Rychtarova, J., Kyselova, J., Matlova, V., Stipkova, S., Matejíckova, J., Marková, M. 2013. Effect of the $\alpha$ s1-, $\alpha$ s2-, $\beta$ - and $\kappa$-casein genotypes on the milk production parameters in Czech goat dairy breeds. GRANT journal ISSN 1805062X, Vol. 2, no. 1, pg. 76-81.

Torres-Vázquez, J.A., FelícitasVázquez, F., Montaldo, H., Ulloa-Arvizu, R., Posadas, M.V., Vázquez, A.G., Morales, R.A.A. 2008. Genetic polymorphism of the as1casein locus in five populations of goats from Mexico. Electronic Journal of Biotechnology, Vol.11 No.3, Issue of July 15, 2008.

Vlaic, A., Balteanu, V., Pop, F., Carsai, T., Suteu, M. 2010. Milk Protein Polymorphisms Study in Some Carpathian Goat Populations Reared in the Central Part of Romania. Bulletin UASVM Animal Science and Biotechnologies, 67(1-2). Pg. 5461. 